\title{
Replication patterns and organization of replication forks in Vibrio cholerae
}

\author{
Caroline Stokke, Torsten Waldminghaus and Kirsten Skarstad
}

Correspondence

Kirsten Skarstad

Kirsten.Skarstad@rr-research.no

Received 1 September 2010

Revised 9 December 2010

Accepted 14 December 2010

\author{
Department of Cell Biology, Institute for Cancer Research, The Norwegian Radiumhospital, Oslo \\ University Hospital, Oslo, Norway
}

\begin{abstract}
We have investigated the replication patterns of the two chromosomes of the bacterium Vibrio cholerae grown in four different media. By combining flow cytometry and quantitative real-time PCR with computer simulations, we show that in rich media, $V$. cholerae cells grow with overlapping replication cycles of both the large chromosome (Chrl) and the small chromosome (Chrll). In Luria-Bertani (LB) medium, initiation occurs at four copies of the Chrl origin and two copies of the Chrll origin. Replication of Chrll was found to occur at the end of the Chrl replication period in all four growth conditions. Novel cell-sorting experiments with marker frequency analysis support these conclusions. Incubation with protein synthesis inhibitors indicated that the potential for initiation of replication of Chrll was present at the same time as that of Chrl, but was actively delayed until much of Chrl was replicated. Investigations of the localization of SeqA bound to new DNA at replication forks indicated that the forks were co-localized in pairs when cells grew without overlapping replication cycles and in higher-order structures during more rapid growth. The increased degree of fork organization during rapid growth may be a means by which correct segregation of daughter molecules is facilitated.
\end{abstract}

\section{INTRODUCTION}

All cells must replicate their genome before division so that each daughter cell receives a copy of the genetic material. In eukaryotic cells, many origins on many chromosomes initiate throughout the replication period (Gilbert, 2001; Woodfine et al., 2004). Prokaryotic cells seem simpler and often have only one chromosome with one origin. There are, however, also many examples of bacteria with multiple chromosomes, such as Rhodobacter sphaeroides (Suwanto \& Kaplan, 1989), Agrobacterium tumefaciens (AllardetServent et al., 1993), members of the genus Burkholderia (Wigley \& Burton, 2000) and all known Vibrio species (Okada et al., 2005).

Here, we set out to investigate in detail the replication of one chromosome relative to the other in Vibrio cholerae. This bacterium has two chromosomes, $\operatorname{ChrI}(2.96 \mathrm{Mb})$ and ChrII (1.07 Mb), each with its unique origin of replication, oriI and oriII (Heidelberg et al., 2000; Trucksis et al., 1998). In slowly growing cells, replication of ChrII has been reported to initiate either simultaneously with that of ChrI (Egan et al., 2004) or much later (Rasmussen et al., 2007). In an earlier study of rapidly growing cells, ChrI replication was found to span two generations, while ChrII was

Abbreviations: $\tau$, generation time; FACS, fluorescence-activated cell sorting; Q-PCR, quantitative real-time PCR.

Five supplementary figures and a supplementary table are available with the online version of this paper. reported to limit its replication to the current generation (Srivastava \& Chattoraj, 2007). ChrI is initiated by the DnaA protein, possibly in a way similar to initiation in Escherichia coli, and ChrII is initiated by the RctB protein in a fashion which seems to be similar to the initiation of some plasmids (Egan \& Waldor, 2003). Overproduction of DnaA and RctB leads to specific overreplication of ChrI and ChrII, respectively (Duigou et al., 2006).

One of the mechanisms that prevents reinitiation of already initiated origins in E. coli is sequestration (Campbell \& Kleckner, 1990; Lu et al., 1994; von Freiesleben et al., 1994). This process functions by specific inactivation of newly replicated origins by the protein SeqA (Slater et al., 1995). Newly synthesized DNA in E. coli is hemimethylated, methylated (by Dam methylase) on the old strand and unmethylated on the new strand, and SeqA binds preferentially to hemimethylated DNA (Brendler et al., 1995; Slater et al., 1995). In V. cholerae, similar control mechanisms may operate, since this organism also harbours seqA and dam genes (Hiraga et al., 2000; Løbner-Olesen et al., 2005). Dam has recently been shown to be required for once-per-cell-cycle initiation of both chromosomes (Demarre \& Chattoraj, 2010; Koch et al., 2010). Both origins of $V$. cholerae have been found to remain hemimethylated longer than other DNA and may thus be subject to sequestration (Saint-Dic et al., 2008). Studies of the intracellular localization of SeqA in E. coli indicate that most of the protein binds to newly synthesized DNA at the replication forks (Molina \& 
Skarstad, 2004). The SeqA protein bound at replication forks forms structures that appear as distinct foci when visualized by fluorescence microscopy (Hiraga et al., 1998; Onogi et al., 1999).

In this work we have investigated the timing of initiation of replication in wild-type $V$. cholerae grown in four different growth media, as well as the localization of replication forks in these cells, visualized as SeqA foci. We find that regulation of replication of ChrII seems to be dependent on the replication of ChrI and that replication forks are colocalized.

\section{METHODS}

Bacterial strains and growth conditions. The bacterial strain used was V. cholerae 2740-80 (CTX $\left.\varphi^{-}\right)$(Pearson et al., 1993). Cells were grown in four different media at $37{ }^{\circ} \mathrm{C}$. These were $\mathrm{AB}$ minimal medium (Clark \& Maaloe, 1967) with $1 \mu \mathrm{g}$ thiamine $\mathrm{ml}^{-1}$ supplemented with either $0.2 \%(\mathrm{v} / \mathrm{v})$ glycerol [glycerol medium, generation time $(\tau)=107 \mathrm{~min}$ ], $0.2 \%$ fructose (fructose medium, $\tau=46 \mathrm{~min}$ ) or $0.2 \%$ glucose and $0.5 \%$ casamino acids (glucose/CAA medium, $\tau=27 \mathrm{~min}$ ), and LB medium ( $\tau=19 \mathrm{~min}$ ). At least three independent experiments were performed for each medium.

At $\mathrm{OD}_{450}$ [or $\mathrm{OD}_{600}$ for Luria-Bertani (LB) medium] 0.15, exponentially growing cells were harvested or treated with $150 \mu \mathrm{g}$ rifampicin $\mathrm{ml}^{-1}$ (Fluka) and $10 \mu \mathrm{g}$ cephalexin $\mathrm{ml}^{-1}$ (Eli Lilly) for four to five generations to allow completion of ongoing rounds of replication. Samples were harvested after the drug treatment. Both exponentially growing cells and cells treated with rifampicin and cephalexin were resuspended in TBSE buffer $(20 \mathrm{mM}$ Tris/ $\mathrm{HCl}$, $\mathrm{pH} 7.5,1 \mathrm{mM}$ EDTA, $130 \mathrm{mM} \mathrm{NaCl}$ ) and fixed in $70 \%$ ethanol.

Flow cytometry. Cells fixed in ethanol were washed in $0.1 \mathrm{M}$ phosphate buffer ( $\mathrm{PB}), \mathrm{pH} 9.0$, and stained overnight $\left(4{ }^{\circ} \mathrm{C}\right)$ in the same buffer with $3 \mu \mathrm{g}$ FITC $\mathrm{ml}^{-1}$. The cells were washed in Trisbuffered saline (TBS) $(20 \mathrm{mM}$ Tris/ $\mathrm{HCl}, \mathrm{pH} 7.5,130 \mathrm{mM} \mathrm{NaCl})$ and stained in the same buffer containing $1.5 \mu \mathrm{g}$ Hoechst $33258 \mathrm{ml}^{-1}$ (Sigma) for at least $30 \mathrm{~min}$.

An ethanol-fixed sample of slowly growing cells from the glycerol medium (the majority of which contained either $1+1$ or $2+2$ chromosomes) was used as an internal standard for calibration of the DNA measurement. The standard was included with every sample during incubation with the Hoechst 33258 stain and was not stained with FITC.

Flow cytometry analysis was then performed using an LSR II flow cytometer (Becton Dickinson) equipped with a $488 \mathrm{~nm}$ argon ion laser and a $355 \mathrm{~nm}$ krypton laser (both Spectra Physics). The FITC fluorescence was collected through a $530 / 30 \mathrm{~nm}$ bandpass filter. A $450 / 50 \mathrm{~nm}$ bandpass filter was used to collect Hoechst 33258 fluorescence. The peaks of the FITC-negative standard were positioned at fixed channels using the photomultiplier tube (PMT) voltage, allowing the DNA content of the FITC-positive sample cells to be accurately calculated (Torheim et al., 2000).

The data obtained from the flow cytometry measurement were analysed by WinMDI or FlowJo software.

Fluorescence-activated cell sorting (FACS). Cells fixed in ethanol were washed in $0.02 \mathrm{M}$ TBS, pH 7.5, and stained in the same buffer containing $1.5 \mu \mathrm{g}$ Hoechst $33258 \mathrm{ml}^{-1}$. The sorting was performed using a FACS DiVa cell sorter (Becton Dickinson) equipped with a
$351 \mathrm{~nm}$ krypton laser. A 440/40 nm bandpass filter was used for collecting Hoechst 33258 fluorescence.

For the visualization of SeqA foci, cells from the different intervals (Fig. 6a) were sorted directly onto glass slides for subsequent immunostaining. The glass slides were washed with ethanol and treated with poly-L-lysine (Sigma) in advance. A total of 25000 cells were sorted from each interval.

For the quantitative real-time PCR (Q-PCR), at least $5 \times 10^{6}$ cells from each interval were sorted into tubes for subsequent isolation of DNA.

Calculation of cell cycle parameters and replication fork distributions. Samples were collected at a point where cells were in balanced exponential growth, and it was assumed that all cells grew in the same way (same replication pattern, cell division pattern, etc.). The sequence of the non-pathogenic strain 2740-80 is highly similar to that of the pathogenic strain N16961 (Vesth et al., 2010). We therefore assumed that the 2740-80 ChrI and ChrII are 2.97 and $1.06 \mathrm{Mb}$, respectively.

For cells grown slowly in fructose or glycerol medium (with replication only in the 'current' $\mathrm{k}$ generation), an Excel-based simulation routine, adapted from the one used by Rasmussen et al. (2007), was used to simulate the theoretical DNA distributions (Supplementary Fig. S1a, b). In our version of the program, the rate of ChrII replication relative to the rate of ChrI replication could be varied. The percentage of cells in $\mathrm{B}, \mathrm{C}$ and $\mathrm{D}$ phase could be iterated until the simulations matched the experimental histograms measured by flow cytometry. These percentages of cells can be used to calculate the duration of the phases:

$\mathrm{p}(\mathrm{t})=\frac{2 \ln 2}{\tau} 2^{-\frac{\mathrm{t}}{\tau}}$

The age distribution (equation 1 ) gives the probability, $\mathrm{p}(\mathrm{t})$, of any cell being age $t, t$ ranging from 0 (newborn) to $\tau$ (dividing). $\tau$ is known from the optical density measurements. The fraction of cells in $\mathrm{B}$ is thus given by:

$\mathrm{P}_{\mathrm{B}}=\int_{\text {Bstart }}^{\text {Bstop }} \mathrm{p}(\mathrm{t}) \mathrm{dt}$

where $t_{\mathrm{Bstart}}$ is 0 , and we want to find $t_{\mathrm{Bstop}}$. So:

$\mathrm{P}_{\mathrm{B}}=-2 \times\left. 2^{-\frac{t}{\tau}}\right|_{0} ^{\text {Bstop }}$

and accordingly:

$t_{\text {Bstop }}=-\tau \frac{\operatorname{In}\left(1-\frac{P_{\mathrm{B}}}{2}\right)}{\operatorname{In} 2}$

Likewise, the same calculations can be performed for the $\mathrm{C}$ phases $\left(t_{\mathrm{C}_{\mathrm{I}} \text { start }}=t_{\mathrm{B} \text { stop }}\right)$ and $\mathrm{D}$. The program WinMDI was used to find the point at which the shift of cells per DNA interval is observed and the initiation of ChrII replication occurs (DNA content of cells at the start of $\mathrm{C}_{\mathrm{II}}$ ).

A new Excel-based simulation routine for $V$. cholerae was built, and works in the same way as a previous simulation routine for E. coli (Skarstad et al., 1985). It was used for simulation of rapidly growing cells (cells grown in LB and glucose/CAA medium), which have started replication in previous generations ( $\mathrm{k}-1$ or $\mathrm{k}-2)$. The new computer routine was used for simulation of the theoretical DNA distributions when $(C+D)>\tau$. C periods obtained by Q-PCR were used as the starting point for the simulations. For cells grown in glucose/CAA, we also calculated a preliminary time point for 
initiation of ChrI from the histogram of cultures treated with rifampicin/cephalexin (Fig. 3b). The number of cells in the first major peak represents the fraction of cells that has not yet initiated replication of ChrI. This percentage $\left(\mathrm{P}_{8.0 \mathrm{Mb}}\right)$ and the age distribution (equation 1) can thus be used to find the time point in the cell cycle at which ChrI initiates, $t_{\mathrm{C}_{1} \text { start }}$, by the equation:

$\mathrm{P}_{8.0 \mathrm{Mb}}=\int_{0}^{\mathrm{C}_{\mathrm{I}} \mathrm{start}} p(t) \mathrm{dt}$

The parameters of the C- and D-phase durations and the initiation point for ChrII were then iterated in the computer routines until the simulated histograms matched the experimental histograms. Different sets of parameters gave different time points in the cell cycle at which one or both chromosomes initiated or terminated replication. The DNA content of the cells was calculated with formulae deduced from the chromosome content of the cells at different time points. For example, newborn cells grown in glucose/CAA medium contain one copy of ChrI and one copy of ChrII, and in addition newly replicated arms of each chromosome. Replication of ChrI has been ongoing for $22 \mathrm{~min}$ of the total ChrI replication period of $30 \mathrm{~min}$, and replication of a new ChrII has been ongoing for $4 \mathrm{~min}$ of the total ChrII replication period of $9 \mathrm{~min}$ (Fig. 1d). The DNA content of the cells at $t=0$ is thus:

$$
\begin{aligned}
& \left(1+\frac{22}{30}\right) \text { size of ChrI }+\left(1+\frac{4}{9}\right) \text { size of } \mathrm{ChrII}= \\
& \left(1+\frac{22}{30}\right) 2.96 \mathrm{Mb}+\left(1+\frac{4}{9}\right) 1.07 \mathrm{Mb}=6.7 \mathrm{Mb}
\end{aligned}
$$

All the formulae used to calculate the amount of DNA in the simulations shown in Fig. 1 are indicated in Supplementary Fig. S2.

Between time points at which one or both of the chromosomes initiates or terminates replication, the number of replication forks, and thus the total replication rate, is constant. Integration of the age distribution (equation 1) over these different periods in the cell cycle gives the fraction of cells within each interval. According to the age distribution, these fractions are plotted in subintervals. A variable standard deviation was applied to the theoretical histograms to simulate biological and methodological variation in the cell cultures. A theoretical histogram was fitted to each experimental histogram, and a distribution of replication forks calculated. Best fit was found using a standard deviation of about $7 \%$.

As explained above, cells will have different numbers of forks in different periods in the cell cycle. For example, integration of the age distribution (equation 1 ) between $t=0$ and $t=5 \mathrm{~min}$ for the cells in glucose/CAA medium resulted in a fraction of cells with four replication forks (Fig. 1d). However, these cells also had four forks at a later stage, from $t=8 \mathrm{~min}$ to $t=23 \mathrm{~min}$, and we must therefore add up the fractions to find the total amount of cells with four forks. The mean values and standard deviations were calculated on the basis of three different experiments (Fig. 5). Cells grown in LB medium produced the same DNA histogram for each experiment, so that the standard deviations (error bars) cannot be distinguished in the figure.

Purification of SeqA antiserum. The SeqA antiserum was raised against purified SeqA protein from E. coli and was found by Western blotting to bind SeqA from $V$. cholerae with little cross-reaction (data not shown).

Cell extract for non-specific absorption of antibody was prepared from a $\Delta$ seqA strain, EBO193 (Torheim et al., 2000). Cells from $1000 \mathrm{ml}$ of exponentially growing culture were harvested, washed once in $10 \mathrm{ml} 50 \mathrm{mM} \mathrm{KH}_{2} \mathrm{PO}_{4} / \mathrm{K}_{2} \mathrm{HPO}_{4}$, $\mathrm{pH} 7.4$, and resuspended in $1.5 \mathrm{ml}$ of the same buffer. Cells were lysed by addition of $250 \mu \mathrm{g}$ egg white lysozyme $\mathrm{ml}^{-1}$ (30 min on ice) followed by freezing and thawing (on ice). The supernatant was collected by centrifugation $\left(18500 \mathrm{~g}, 30 \mathrm{~min}, 4{ }^{\circ} \mathrm{C}\right)$, and cell extract was frozen in liquid nitrogen and stored at $-80{ }^{\circ} \mathrm{C}$.

Precipitation of non-specific antibody was performed by dilution of SeqA antibody about 100 -fold with $\Delta$ seqA cell extract to a final volume of $470 \mu \mathrm{l}$. A $30 \mu \mathrm{l}$ volume of PBST ( $140 \mathrm{mM} \mathrm{NaCl}, 2 \mathrm{mM}$ $\mathrm{KCl}, 8 \mathrm{mM} \mathrm{Na}_{2} \mathrm{HPO}_{4}, 1.5 \mathrm{mM} \mathrm{KH} \mathrm{PO}_{4}, 0.05 \%$ Tween 20) containing $10 \mathrm{mM}$ EDTA was added followed by incubation on ice for $1 \mathrm{~h}$. The supernatant was collected by centrifugation $(21000 \mathrm{~g}, 15 \mathrm{~min}$, $4{ }^{\circ} \mathrm{C}$ ) and used as SeqA antibody solution.

Immunostaining and fluorescence microscopy. A glass slide (cleansed with ethanol) was incubated with $20 \mu \mathrm{l}$ poly-L-lysine for $5 \mathrm{~min}$ before the slide was washed with distilled water and air-dried. A $10 \mu$ volume of the ethanol-fixed cell suspension was dropped onto the slide and air-dried. After washing and drying, the dried cell area was covered with $100 \mu \mathrm{l}$ lysozyme solution [2 mg lysozyme $\mathrm{ml}^{-1}$ in $25 \mathrm{mM}$ Tris/ $\mathrm{HCl}$ (pH 7.5), $50 \mathrm{mM}$ glucose, $10 \mathrm{mM}$ EDTA] and incubated at room temperature for $8 \mathrm{~min}$. Then, the slide was covered with $1 \mathrm{ml}$ PBST for $30 \mathrm{~s}$ and inclined to remove the solution. This step was repeated five times. The slide was covered with $1 \mathrm{ml} 99 \%$ methanol for $1 \mathrm{~min}$, inclined and air-dried. A $100 \mu \mathrm{l}$ volume of PBST containing $2 \%$ BSA (PBST-BSA) was placed on the slide to block the sample and was removed after 15 min by inclining the slide. A $25 \mu \mathrm{l}$ volume of the SeqA antibody solution (first step antibody) was placed on the slide, covered with a cover glass and left for $1 \mathrm{~h}$ at room temperature in a moisture chamber. The cover glass was then removed and the slide washed 15 times with $1 \mathrm{ml}$ PBST. The sample on the slide was blocked again with PBST-BSA for 15 min and airdried. A $20 \mu \mathrm{l}$ volume of 500-fold-diluted Cy3 anti-rabbit IgG red fluorescence (second step antibody) was placed on the slide, covered with a cover glass and incubated for $1 \mathrm{~h}$ in a dark moisture chamber. The slide was then washed as before, 15 times with PBST. The sample was covered with $10 \mu \mathrm{l}$ mounting medium containing Hoechst 33258 [40\% (v/v) glycerol, $0.02 \mathrm{M}$ PBS (pH 7.5), $5 \mu \mathrm{g}$ Hoechst $33258 \mathrm{ml}^{-1}$ ] and covered with a cover glass.

Visualization of immunostained cells was performed using a Zeiss Axioplan 2 phase-contrast/fluorescence microscope equipped with a numerical aperture 1.40 objective and a BP546/12 excitation filter. DNA was visualized with a BP365/12 excitation filter. Pictures were taken using a MicroMax charge-coupled device (CCD) camera (Princeton Instruments) that was connected to a computerized image analysis system (Zeiss AxioVision 4.6). The optical images, which showed cell outlines, were merged with the fluorescent images, which showed SeqA proteins.

Determination of GATC-site distributions. SeqA binds to pairs of hemimethylated GATC sites. There are at least 17 different spacings between the sites that are bound by E. coli SeqA in in vitro gel-shift experiments (Brendler et al., 2000). These are 6, 7, 8, 10, 11, 12, 13, $14,18,19,20,21,22,23,29,30$ and $31 \mathrm{bp}$ (for example, the sequence GATCTGATC has a spacing of $5 \mathrm{bp}$ ).

A program was written that identified all the pairs of GATC sites with favourable spacings along each of the $V$. cholerae chromosomes. The maps in Supplementary Fig. S3 show potential SeqA binding sites as a black bar for each GATC pair, on the two chromosomes.

Isolation of chromosomal DNA and Q-PCR. A $7.5 \mathrm{ml}$ volume of $V$. cholerae culture was mixed with $7.5 \mathrm{ml}$ ice-cold killing buffer (20 mM Tris, $5 \mathrm{mM} \mathrm{MgCl}_{2}, 20 \mathrm{mM} \mathrm{NaN}_{3}$ ) and centrifuged for $3 \mathrm{~min}$ at $6000 \mathrm{~g}$ and $4{ }^{\circ} \mathrm{C}$. The supernatant was discarded and the pellet resuspended in $300 \mu \mathrm{l}$ Tris-EDTA (TE) buffer containing $40 \mu \mathrm{l} 10 \%$ SDS and $3 \mu \mathrm{l} 0.5 \mathrm{M}$ EDTA. After incubation for $5 \mathrm{~min}$ at $65{ }^{\circ} \mathrm{C}$, $750 \mu \mathrm{l}$ 2-propanol was added before centrifugation at $15600 \mathrm{~g}$ for $5 \mathrm{~min}$. The pellet was resuspended in $500 \mu \mathrm{l} \mathrm{TE}$ buffer, and $2 \mu \mathrm{l}$ 

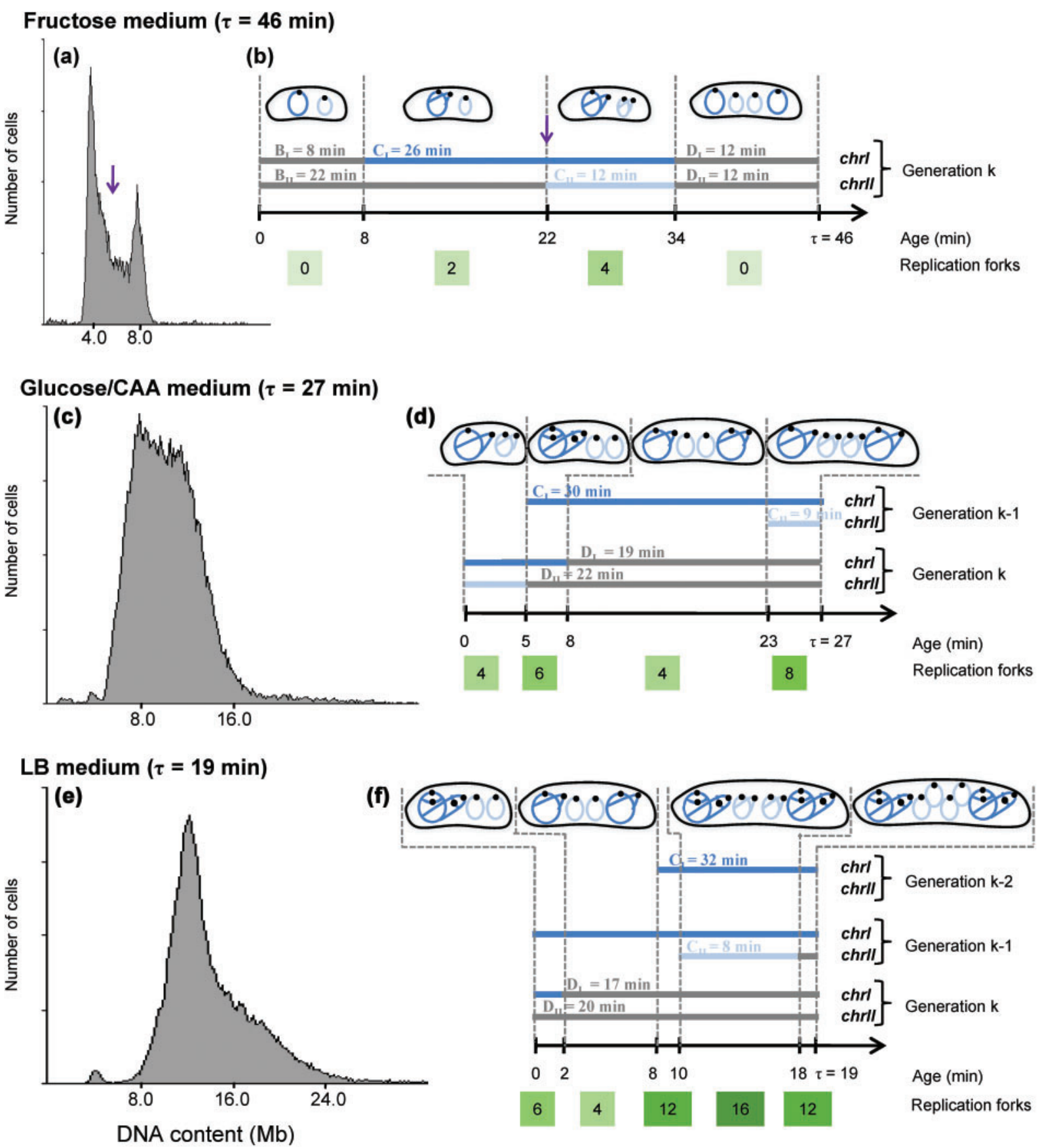

Fig. 1. Overlapping replication rounds in $V$. cholerae cells during rapid growth. (a, c, e) DNA histograms of cells grown in different media obtained by flow cytometry. (a) In poor medium (fructose), cells contained from 4.0 to 8.0 Mb DNA, which corresponds to one copy of Chrl and one of Chrll or two copies of each. (c, e) When grown in richer media, the cells contained more DNA, and thus had overlapping rounds of replication. (b, $d, f)$ Calculated replication patterns at the three different growth rates. The replication patterns were determined from the best-fit simulated DNA distributions. The corresponding simulated distributions are shown in Fig. 2(a) and Supplementary Fig. S1 (b, c). The black horizontal arrows indicate time axes. Each pair of lines above these axes represents one generation, where the 'current' generation is denoted k, the 'mother' $k-1$ and the 'grandmother' k-2. The dark-blue lines represent periods of Chrl replication $\left(\mathrm{C}_{1}\right)$, and the light-blue lines periods of $\mathrm{Chrll}$ replication $\left(C_{\| l}\right) . D_{l}, D_{\|}$and $B$ phases are shown in grey. Time points at which initiation or termination occurs are marked on the time axes, and the numbers of replication forks between these points are indicated below the axes (green boxes). Cells are drawn schematically for each life cycle with Chrl in dark blue, Chrll in light blue, and the origins as black dots [in ( $f$ ), the chromosome configuration in one interval, age 8-10 min, is not shown]. The purple arrow indicates the point of initiation of Chrll in cells grown in fructose medium. 
RNase A (25 mg ml $\left.{ }^{-1}\right)$ was added and incubated for $30 \mathrm{~min}$ at $65{ }^{\circ} \mathrm{C}$ Subsequently, $2 \mu \mathrm{l}$ proteinase $\mathrm{K}\left(25 \mathrm{mg} \mathrm{ml}^{-1}\right)$ was added and samples were incubated at $37^{\circ} \mathrm{C}$ for 15 min followed by phenol extraction and precipitation with ethanol and sodium acetate. Precipitated DNA was resuspended in $50 \mu \mathrm{l}$ double-distilled $\mathrm{H}_{2} \mathrm{O}\left(\mathrm{ddH}_{2} \mathrm{O}\right)$. Q-PCRs were carried out in triplicates of $25 \mu \mathrm{l}$ each. Chromosomal DNA was digested with EcoRI to allow optimal access of primers to the template. About $10 \mathrm{ng}$ digested DNA was used as template in $10 \mu \mathrm{l}$ $\mathrm{ddH}_{2} \mathrm{O}$ and added to a mixture of $12.5 \mu \mathrm{l}$ TaqMan Gene Expression mix (Applied Biosystems) and $2.5 \mu$ l three-primer mix $(9 \mu \mathrm{M}$ each forward and reverse primer and $2.5 \mu \mathrm{M}$ probe) in 96-well PCR plates. Primer pairs for oriI (orilfw, orilrv and orilprobe), terI (terlCfw, ter1Crv, ter1Cprobe), oriII (ori2fw, ori2rv, ori2probe) and terII (ter2Rfw, ter2Rrv, ter2Rprobe) were used in separate reactions. For a list of primers, see Supplementary Table S1. Reactions were carried out with a 7500 Real-Time PCR system (Applied Biosystems). The system software was used to calculate the cycle number at which the fluorescence crossed the threshold ( $C_{\mathrm{t}}$ value), which was transformed to a relative value of template DNA. The standard deviation for three replicates was about $3 \%$. The relative values for three different experiments for each growth condition were used to calculate orilter, orilori and ter/ter ratios (Table 1) relative to the respective ratios of DNA from standard samples (cells grown in glycerol medium to stationary phase). Primer pairs for oriIl, terI and terII gave comparable signals in the measurement of standard DNA, whereas the primer pair for oriI gave a somewhat lower signal. The ratio of origin copies to terminus copies in an exponentially growing population is given by the formula ori/ter $=2^{\frac{C}{\tau}}$, where $C$ is the time it takes to replicate the chromosome from the origin to the terminus and $\tau$ is the doubling time of the population (Bremer \& Churchward, 1977). C periods were calculated using this formula with the indicated variation according to the standard deviation. The Q-PCR analysis of sorted cells was carried out twice for each of two different cell sortings.

\section{RESULTS}

$V$. cholerae 2740-80 was grown in media that gave four different growth rates (see Methods). Cells in exponential steady-state growth were harvested at an optical density of 0.15 and subsequently used for at least three types of measurement: (i) DNA contents of cells were measured by flow cytometry, (ii) the duration of replication periods was estimated by Q-PCR, and (iii) the localization of the SeqA protein was determined by immunofluorescence microscopy. The DNA histograms and replication period durations were used in computer simulations to calculate the different patterns of replication.

\section{Chrll replication occurs at the end of the Chrl replication period}

The DNA histogram of $V$. cholerae grown in fructose medium (with $\tau=46 \mathrm{~min}$ ) shows that through the cell cycle cells contain either 4.0 or $8.0 \mathrm{Mb}$ DNA, or amounts of DNA in between these values (Fig. 1a). This indicates that cells in the first peak contain one copy of ChrI and one copy of ChrII, and are thus in the pre-replication phase (B period). Cells in the second peak contain two copies, one of both ChrI and II, and are in the post-replication, D, phase. From the shape of the DNA distribution in the $C$ phase, between the peaks, it can be seen that the number of cells per DNA channel is lower in the second part of the replication period than in the first. The reason for lower numbers of cells per channel is a higher total rate of DNA synthesis in the cells in late $\mathrm{C}$ phase compared with the cells in early $\mathrm{C}$ phase (i.e. replication at four forks compared with replication at two forks). This observation indicates that replication of ChrI is initiated first and goes on for a while before the replication of ChrII is initiated. The exact point at which the shift to a lower number of cells per channel occurs can be seen in the DNA histograms (marked by an arrow, Fig. 1a), and the time point of initiation of ChrII in the cell cycle can be calculated from this DNA amount (see arrow, Fig. 1b). Computer simulations were performed to obtain the fractions of cells in the four intervals $\mathrm{B}$, early $\mathrm{C}$, late $\mathrm{C}$ and $\mathrm{D}$ that gave the best fit to the experimental histogram (see Methods). The durations of cell cycle periods can be calculated from these fractions, taking the exponential age distribution into consideration. The result, that ChrII replication (with duration $\mathrm{C}_{\mathrm{II}}=12 \mathrm{~min}$ ) is performed in the late part of the C phase $\left(\mathrm{C}_{\mathrm{I}}=26 \mathrm{~min}\right)$ (Fig. 1b), is in accordance with the results of Rasmussen et al. (2007).

Table 1. orilter, orilori and terlter ratios and $C$ period durations derived from Q-PCR

\begin{tabular}{|c|c|c|c|}
\hline oriI/terI ratio & $1.6 \pm 0.1$ & $2.5 \pm 0.1$ & $3.6 \pm 0.5$ \\
\hline oriII/terII ratio & $1.1 \pm 0.2$ & $1.2 \pm 0.2$ & $1.3 \pm 0.0$ \\
\hline terI/terII ratio & $1.0 \pm 0.1$ & $0.9 \pm 0.0$ & $0.9 \pm 0.1$ \\
\hline $\mathrm{C}_{\mathrm{I}}$ period $(\mathrm{min})$ & $30(26-33)^{\star}$ & $35(34-37)^{\star}$ & $35(31-38)^{\star}$ \\
\hline $\mathrm{C}_{\mathrm{II}}$ period $(\mathrm{min})$ & $9(0-19)^{*} \dagger$ & $7(0-13)^{\star}$ & $8(7-8)^{\star}$ \\
\hline
\end{tabular}

${ }^{*} \mathrm{C}$ period values are calculated from the original ori/ter ratios to two decimal places by the formula ori/ter $=2^{\frac{\mathrm{C}}{\mathrm{t}}}$. The values in parentheses are the estimated range of $\mathrm{C}$ values given by the orilter ratio $\pm \mathrm{SD}$.

$\dagger$ Subtraction of the SD from the orilter ratio gave a ratio below one and thus a negative value for the $\mathrm{C}_{\mathrm{II}}$ period. The minimal value was therefore set at 0 min. The difference between the copy numbers of oriII and terII was considered too small for measurements of C with Q-PCR in this case, and the value obtained was not used further. 
The DNA histogram of cells growing more slowly (in glycerol medium, $\tau=107 \mathrm{~min}$ ) yielded similar values for $\mathrm{C}$ and $\mathrm{D}$ periods and considerably extended $B$ periods $\left(B_{I}=60 \mathrm{~min}\right.$ and $\mathrm{B}_{\mathrm{II}}=76 \mathrm{~min}$ ) (Supplementary Fig. S4). Replication of ChrII $\left(\mathrm{C}_{\mathrm{II}}=13 \mathrm{~min}\right)$ also seemed to occur during the late part of $\mathrm{C}\left(\mathrm{C}_{\mathrm{I}}=29 \mathrm{~min}\right)$ under these conditions.

\section{Both Chrl and Chrll have increased copy numbers during rapid growth}

Bacteria that are capable of rapid growth, such as E. coli and Bacillus subtilis, allow replication to span more than one generation, and can in this way achieve generation times that are much shorter than the time required to complete duplication of the chromosome (Cooper \& Helmstetter, 1968; Skarstad et al., 1985). V. cholerae ChrI has also been reported to initiate replication in the mother cell, whereas ChrII has been reported to limit replication to the 'current' generation (Srivastava \& Chattoraj, 2007). Here, we found that newborn $V$. cholerae cells grown in the rich media glucose/CAA and LB contained about 6.7 and 9.9 Mb DNA, respectively (Fig. 1c, e). These DNA contents correspond to much more than one copy of the genome, and the cells must therefore initiate replication in previous generations. We simulated theoretical DNA distributions, and estimated the best fit to the experimental histograms, to determine the details of the replication patterns.

Cells grown in LB $(\tau=19 \mathrm{~min})$ gave DNA distributions ranging from 9.9 to $19.8 \mathrm{Mb}$ DNA (Fig. 1e). To obtain an independent measure of the duration of the $C$ phase, we performed Q-PCR of the origin and terminus regions (Table 1). The ratio of origin copies to terminus copies in an exponentially growing population is given by the formula ori/ter $=2^{\frac{C}{\tau}}$, where $C$ is the time it takes to replicate the chromosome from the origin to the terminus and $\tau$ is the doubling time of the population (Bremer \& Churchward, 1977). In the following simulations, the C and $\mathrm{D}$ values were iterated to find the best theoretical fits to the experimental DNA histograms. At different time points of the cell cycle, the corresponding DNA content was calculated by our Excel-based simulation program. The number of cells in the intervals between these points was found and then plotted in subintervals according to the age distribution. Calculation points were whenever origins fire (which will start new replication forks, cause an increase in the total replication rate and thus fewer cells per DNA interval), replication rounds finish (causing a decrease in the number of replication forks) or cells divide. Our estimated $\mathrm{C}_{\mathrm{I}}$ duration was $32 \mathrm{~min}$ and that of $\mathrm{C}_{\mathrm{II}}$ was $8 \mathrm{~min}$; this is in accordance with both our Q-PCR values and earlier findings (Dryselius et al., 2008; Srivastava \& Chattoraj, 2007). With this replication pattern $\left(C_{I}=32, C_{I I}=8, D_{I}=17\right.$ and $D_{I I}=20$ min; simulation in Fig. 2a), cells initiate replication of ChrI at four origins in the middle of generation $\mathrm{k}$ - 2 (i.e. in the 'grandmother'), whereas initiation of ChrII occurs in generation k-1 (the 'mother') at two origins (Fig. 1f). Simulations in which the two copies of ChrII did not initiate replication at the same time, but some minutes after each other, also fit the experimental histogram relatively well (data not shown). These results thus indicate that the cells grow with between two and four oriII in LB medium. It is, however, not possible from these measurements to determine whether the two ChrII origins initiate at exactly the same time or not.

A simulation with D-phase parameters so that ChrI initiated replication in the k-1 generation (i.e. in the 'mother') and ChrII in the current, $k$, generation $\left(D_{I}=6 \mathrm{~min}\right.$ and $\mathrm{D}_{\mathrm{II}}=11 \mathrm{~min}$; see Supplementary Fig. S5a for corresponding replication pattern) was made to test the earlier-suggested replication model (Srivastava \& Chattoraj, 2007). This simulated DNA histogram did not fit well, both because the shape was clearly wrong and because the DNA contents became too low (5.8-11.6 Mb; Fig. 2b). A simulation with the same $\mathrm{D}_{\mathrm{I}}$-phase duration as that of the cells grown in fructose medium $\left(D_{I}=12\right)$ and a $D_{\text {II }}$ phase $\left(D_{\text {II }}=15 \mathrm{~min}\right)$ which allows termination of ChrII slightly before termination of ChrI (and is in accordance with oriI/oriII results from the Q-PCR), also did not fit well and gave DNA values that were too low (8.0-16.0 Mb; Fig. 2c and Supplementary Fig. S5b). These badly fitting simulations are included here to demonstrate that the distribution of DNA contents in the cell culture yields precise information about the degree of replication cycle overlap.

Cells grown in glucose/CAA medium $(\tau=27 \mathrm{~min})$ contained DNA amounts from about 6.7 to $13.4 \mathrm{Mb}$ DNA (Fig. 1c). A similar procedure of simulation was undertaken as for the cells grown in LB, and the resulting histogram is shown in Supplementary Fig S1(c). The parameters that gave the best fit to the shape and DNA values of this distribution were $C_{I}=30, D_{I}=19, C_{I I}=9$ and $\mathrm{D}_{\mathrm{II}}=22 \mathrm{~min}$ (Fig. 1d), which are quite similar to those found for cells grown in LB. Replication of both chromosomes was found to span two generations.

\section{The origin of Chrll fires much later than the origin of Chrl, but is ready at the same time}

In the analysis of chromosome replication in E. coli, drug treatment which inhibits initiation of replication but allows ongoing replication forks to finish is often used to determine the numbers of origins per cell (Skarstad et al., 1986). Rifampicin inhibits the transcription necessary for initiation at ori $C$, while ongoing forks are allowed to finish. Cephalexin is also added to inhibit cell division (Boye \& Løbner-Olesen, 1991). Thus, after a few hours of drug treatment, cells will contain $2^{n}(n=0,1,2,3 \ldots)$ fully replicated chromosomes if initiation is synchronous. The number of chromosomes in a cell then corresponds to the number of origins present in the cell at the time of drug action.

We subjected $V$. cholerae $2740-80$ cells to this treatment and found that cells grown in fructose responded in a 

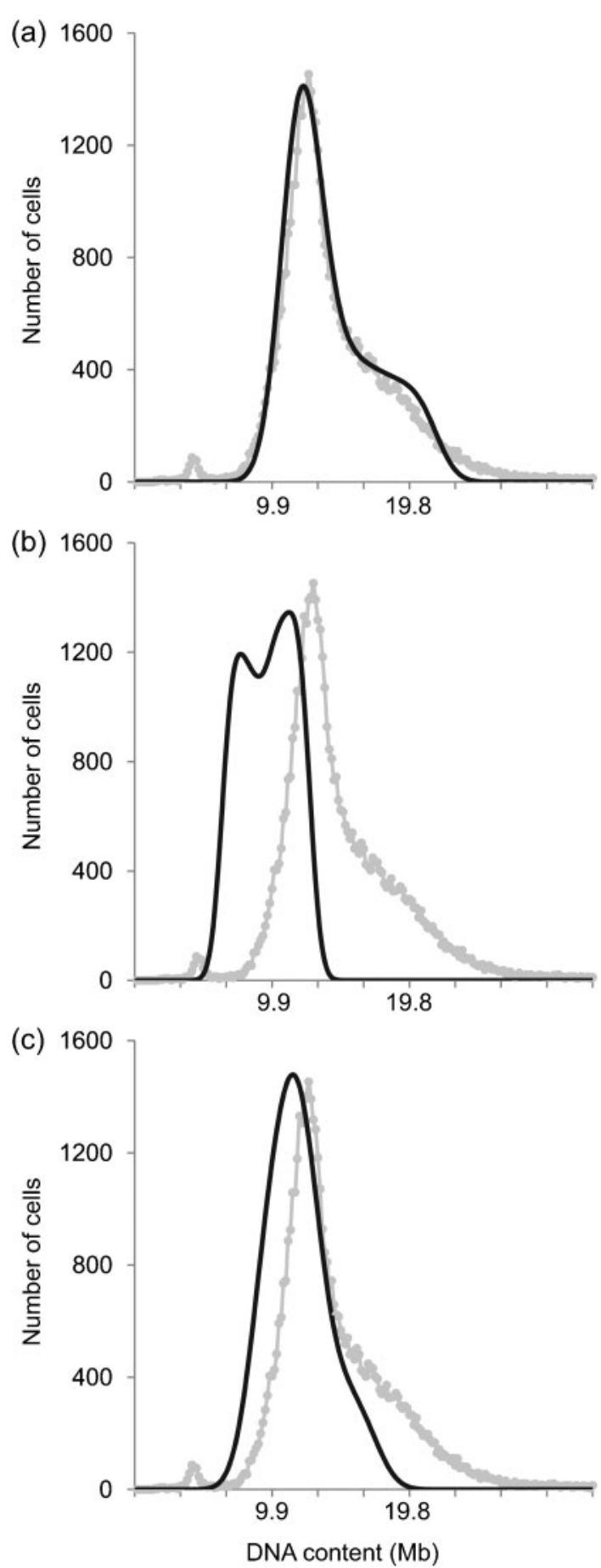

similar way to $E$. coli cells and in accordance with results reported for V. cholerae (Egan et al., 2004; Rasmussen et al., 2007). Cell counting by Coulter Counter showed that cephalexin inhibits cell division in $V$. cholerae also (data not shown). About $20 \%$ of the cells had a DNA content corresponding to one ChrI plus one ChrII (4.0 Mb) and about $80 \%$ had a DNA content corresponding to two ChrI and two ChrII (8.0 Mb) (Fig. 3a). The number of cells with one and two ChrI was as expected from the replication pattern (Fig. 1b), indicating that rifampicin inhibits
Fig. 2. Flow cytometry analyses indicate high copy numbers of both $V$. cholerae chromosomes. (a-c) The experimental flow cytometry histograms of cells growing exponentially in LB medium (grey connected dots) were compared with histograms from different simulations of replication patterns (black lines). (a) Simulation with iterations of C-phase durations and D-phase values until a good fit was obtained. The corresponding replication pattern is shown in Fig. 1(f). (b) Simulation with the same C-phase durations, assuming initiation of Chrl in the 'mother' generation and initiation of Chrll in the 'current' generation (see Supplementary Fig. S5a for replication pattern). (c) Simulation with the same Cphase durations, and D-phase length as for cells in fructose medium (see Supplementary Fig. S5b for replication pattern). Details of simulations can be found in Methods.

initiation of replication from oril. If rifampicin also inhibited initiation from oriII, about $30 \%$ of the cells would have two ChrI but only one ChrII (7.0 Mb). Cells with this amount of DNA were not found. Since this population was missing, oriII can be initiated even in the absence of transcription and protein synthesis.

In accordance with earlier reports we found that cells grown in LB did not finish ongoing rounds of ChrI replication in the presence of rifampicin and cephalexin (Srivastava \& Chattoraj, 2007). A subpopulation of the cells was capable of finishing with $4+4$ chromosomes, while a large proportion of the rest of the cells contained a higher amount of DNA (data not shown).

Cells grown in glucose/CAA medium finished ongoing rounds of replication in the majority of the cells in the presence of rifampicin and cephalexin (Fig. 3b). Thirty per cent of the cells contained an amount of DNA equivalent to two ChrI and two ChrII, and the rest were judged to contain four ChrI and four ChrII, although this was not seen clearly because some cells had not completed ongoing rounds. The reason for this is not known, but it may be that the reservoir of nucleotides is not large enough to support completion of all replication forks in the absence of protein synthesis. Adding nucleosides to the culture for improvement of the run-out histogram did not, however, yield any effect (data not shown). The result supports the above finding that the oriII initiations, which allow ChrII to reach the same number as ChrI, are not inhibited by rifampicin. The result also shows that when a matching number of chromosomes was reached, further initiation of oriII was inhibited.

\section{ori/ter ratios of sorted subpopulations of V. cholerae cells confirm that Chrll can initiate replication in previous generations}

To independently verify the replication pattern with the high copy numbers of ChrII found for $V$. cholerae cells grown in LB medium, we sorted cells by FACS and measured the marker frequencies of origins and termini 


\section{(a) Fructose medium}

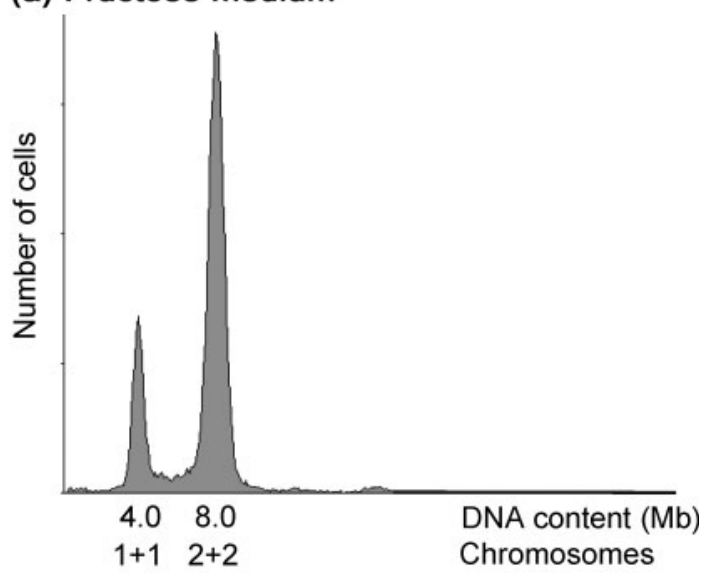

(b) Glucose/CAA medium

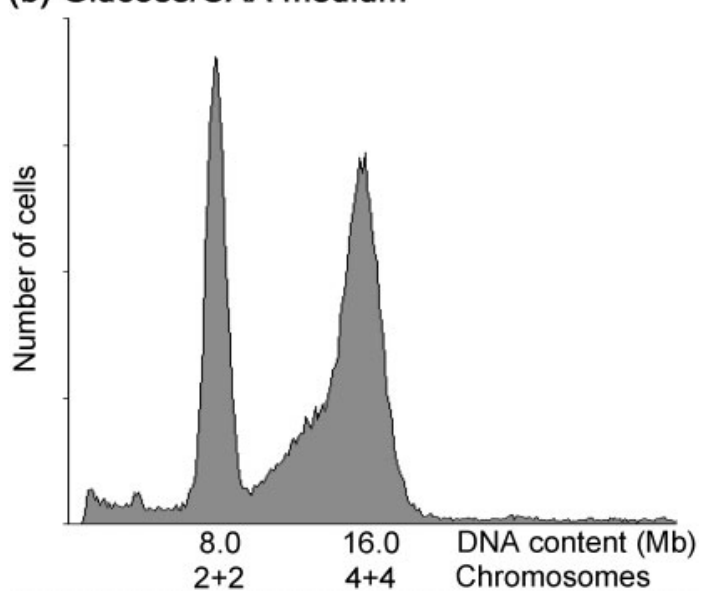

Fig. 3. V. cholerae cells accumulate matching numbers of chromosomes after replication run-out. DNA histograms of cells grown in fructose (Fig. 1a) and glucose/CAA medium (Fig. 1c) and incubated with rifampicin and cephalexin.

in the subpopulations by Q-PCR. Cells from two intervals, P1 and P2, were collected (Fig. 4b), and the oriI/terI, oriII/terII, oriI/oriII and terI/terII ratios determined by Q-PCR (Fig. 4c). According to our simulated replication pattern (Fig. 1f), cells in P1 contain four oriI and either one or two terI (which gives a theoretical oriI/ terI ratio of about 3), and two oriII and two terII. The cells in P2 have initiated another round of replication of both ChrI and ChrII. We calculated the theoretical ori and ter frequencies for the two intervals (grey bars in Fig. 4c) and found the agreement with the experimental data (purple and yellow bars in Fig. 4c) to be good. The result supports our proposed replication pattern (Fig. 1f). Notice especially that the high copy number of ChrI, combined with the oriI/oriII ratio of 2 , suggests that ChrII initiates replication of two copies simultaneously. If one copy of ChrII were replicated first, during the first half of a cell's life, and then the other copy during the second half, the oriI/oriII value would have been $4 / 3$, i.e. about
1.3 , in the young cells and 2 in the old. The Q-PCR experiments indicate that the value is around 2 in both young and old cells.

\section{Co-localization of the replication forks in $V$. cholerae cells grown in poor media}

In E. coli the new DNA at replication forks can be identified by immunostaining with anti-SeqA antibody (Molina \& Skarstad, 2004). The $V$. cholerae SeqA protein is $69 \%$ similar to SeqA in E. coli. It can therefore be assumed that most of the SeqA protein in the $V$. cholerae cell is also bound to newly replicated DNA if the distribution of GATC sites is similar to that of E. coli. A computer routine which identifies pairs of GATC sites with distances favourable for SeqA binding was constructed, using the same criteria as those used earlier for such analyses in $E$. coli (Brendler et al., 2000). It was found that both ChrI and ChrII of $V$. cholerae have a slightly higher frequency of such pairs of GATC sites than the genome of E. coli (Supplementary Fig. S3). We therefore assume that SeqA binding also occurs at the replication forks in $V$. cholerae.

$V$. cholerae cells analysed by flow cytometry were also subjected to immunofluorescence microscopy to determine the localization of SeqA, and thus the localization of newly replicated, hemimethylated DNA. The SeqA foci distributions (Fig. 5a, d, g, j) were compared with the replication fork distributions (Fig. 5b, e, h, k) to estimate the degree of colocalization for each medium. The replication fork distributions were determined from the calculated replication patterns (see Methods).

$V$. cholerae grown with glycerol as carbon source had a doubling time of $107 \mathrm{~min}$ and no overlapping replication rounds (Supplementary Fig. S4b). Calculation of cell cycle parameters yielded $22 \% \mathrm{C}$-phase cells and about $6 \%$ in late $\mathrm{C}$ (with both ChrI and ChrII replicating). Immunofluorescence microscopy showed that about $74 \%$ of the cells had no foci, $21 \%$ contained one and $5 \%$ two SeqA foci (Fig. 5a). The results indicate that most cells in early $\mathrm{C}$ phase (replicating only ChrI) contain one SeqA focus and most cells in late C (replicating both ChrI and ChrII) contain two SeqA foci during slow growth. This indicates that pairs of replication forks stay colocalized during most of the replication period.

Similar results were found for cells grown in fructose medium. Here, cells with no, one, two or three foci were observed (Fig. 5d, f). The cells with two or three foci were larger than the cells with no or one focus. This further indicates that cells with one SeqA focus were in early C phase and contained two forks, whereas the cells with two or three foci were in late $\mathrm{C}$ with four forks. During the above experiments it was noticed that whereas most cells with one focus were relatively small, about $13 \%$ of them were large, had a septum, and had the focus positioned near the septum (cell with arrow in Fig. 5f). It is possible either that these cells are still in late $C$ phase or that a SeqA structure persists after replication is finished. It is likely that in the individual cell, 
(a)
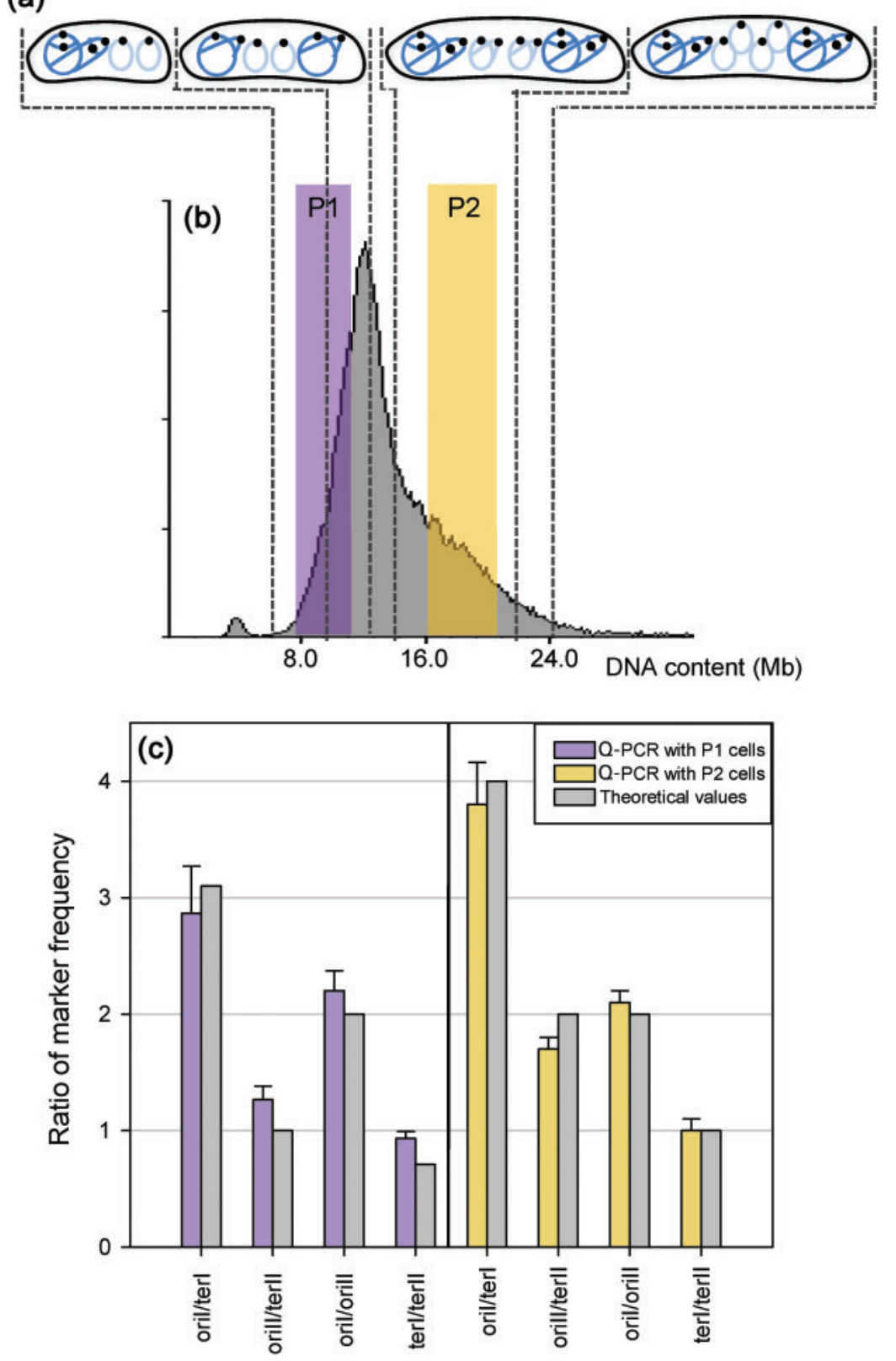

Fig. 4. Marker frequency analyses of sorted cells confirm the replication pattern of LBgrown $V$. cholerae. $(a, b)$ Cells from the DNA intervals P1 (purple) and P2 (yellow) were collected by FACS. Schematic of theoretical chromosome configurations at the indicated intervals in the DNA distribution (based on the cell cycle parameters shown in Fig. 1f). Note that P1 will contain cells with both the first and the second chromosome configuration. (c) QPCR measurements of origin and terminus frequencies in cells from the two intervals (purple and yellow bars) compared with the calculated theoretical values (grey bars). one chromosome terminates replication slightly before the other, with methylation of the GATC sites of this chromosome in the terminus region following 1-2 min later (Waldminghaus \& Skarstad, 2010). The terminus region of the other chromosome will then contain the only hemimethylated DNA in the cell. SeqA bound here might therefore be more difficult to displace, because no other hemimethylated binding sites exist to compete for binding, thus possibly giving rise to persisting SeqA structures.

\section{Replication fork organization during the cell cycle in $V$. cholerae}

Cells grown in fructose medium were sorted by FACS according to DNA content. Narrow intervals from the left side of the B-phase peak, the right side of the D-phase peak and from early and late $C$ phase (see narrow coloured stripes in Fig. 6a) were chosen in order to collect cells as representative as possible. The sorting procedure typically yielded about $96 \%$ purity. The sorted cells were subjected to immunofluorescence microscopy and the numbers of SeqA foci per cell scored (Fig. 6c). Most of the B-phase cells (79\%) had no SeqA focus, whereas most cells (50-65\%) from the other categories had one focus. Many of the late C-phase cells had two foci (31\%) and some had three (10\%). Most of the D-phase cells contained one intense focus at midcell, and resembled the cells with a focus at the septum referred to above. From the SeqA focus distributions in the four categories of cells a total focus distribution was calculated and found to be essentially the same as that 


\section{Glycerol medium}

(a)

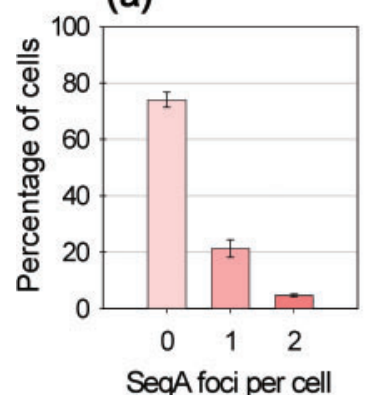

SeqA foci per cell (b)

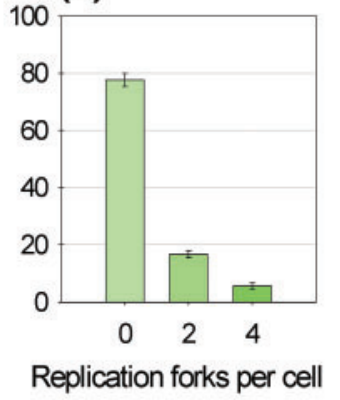

(c)
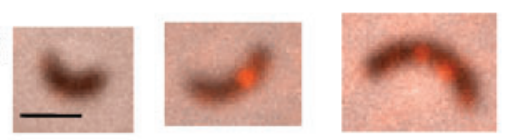

Fructose medium

(d)

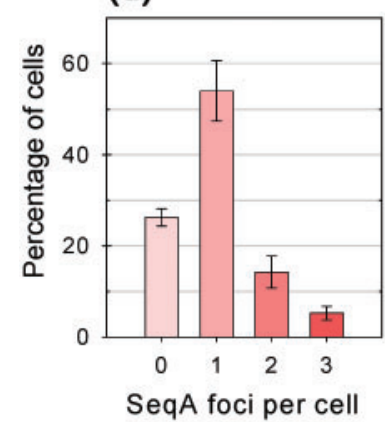

(f)

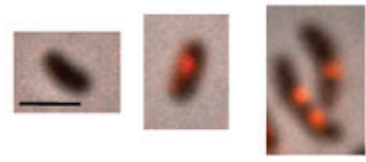

(e)
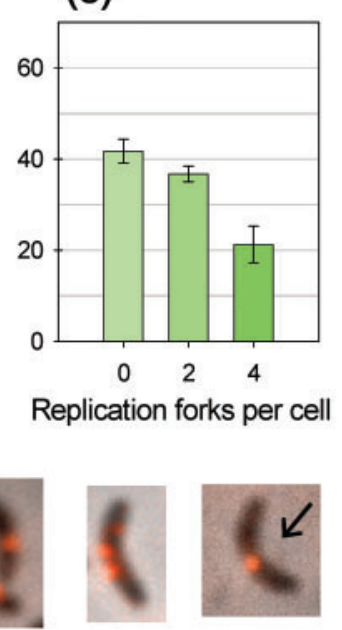

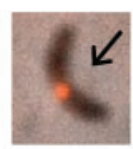

Glucose/CAA medium
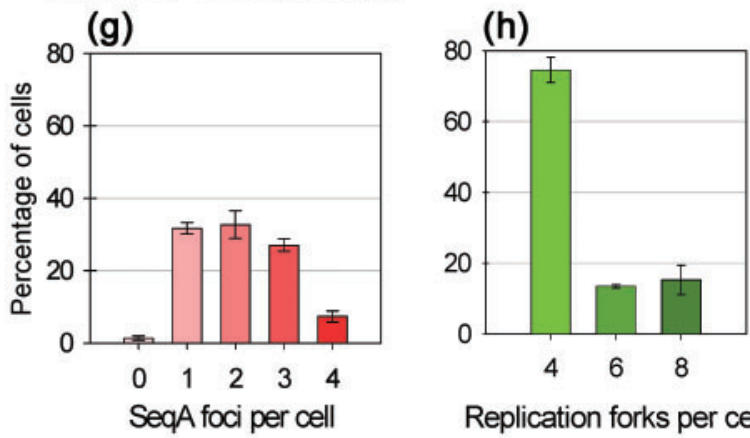

Replication forks per cell

(i)

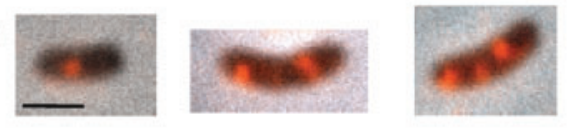

LB medium
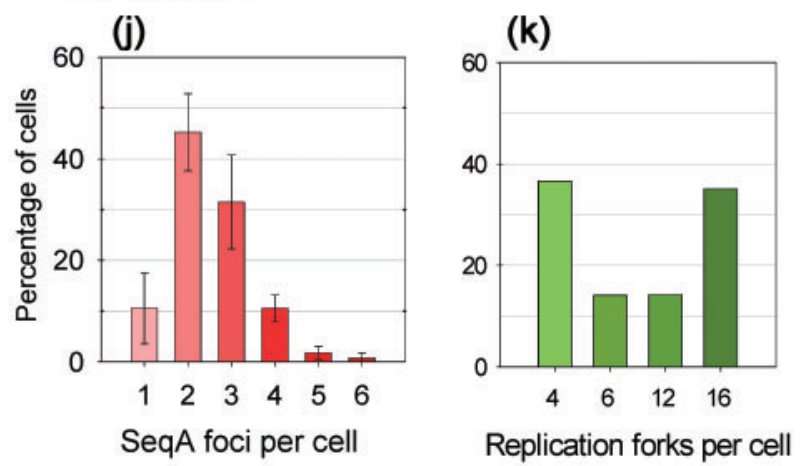

(l)
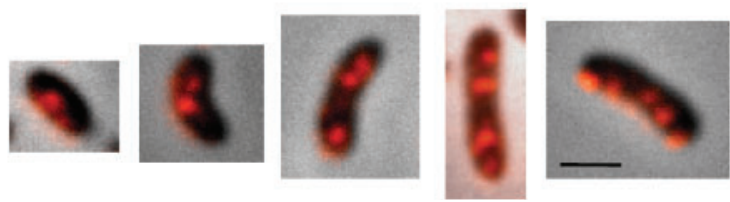

Fig. 5. Replication fork co-localization. Fixed cell samples used for flow cytometry in Fig. 1 and Supplementary Fig. S4 were also immunostained using anti-SeqA antibody and subjected to fluorescence microscopy. (a, d, g, j) Distributions of SeqA foci per cell. At least 100 cells were counted in each experiment. (b, e, h, k) Replication fork distributions were determined from the replication patterns of the simulations. (c, $f, i, l)$ Representative cells from each of the four growth media. Some of the cells grown in poor media had one focus positioned at the septum [see arrow in (f)]. Bars, $1 \mu \mathrm{m}$ (applies to all images).

of the unsorted cells. The results support the above indication that pairs of $V$. cholerae replication forks are co-localized during most of the replication period when the cells grow in poor medium.

\section{A more extensive organization of replication forks during rapid growth}

The rapidly growing cells were also subjected to immunofluorescence microscopy and the numbers of SeqA foci per cell were scored. A comparison of the numbers of forks per cell with the numbers of SeqA foci indicated that the increase in fork numbers was much larger than the increase in numbers of SeqA foci (Fig. 5g-1). Cells grown in glucose/ CAA medium had four, six or eight replication forks and most often one, two or three foci, and most cells grown in LB medium had four or 16 forks and two, three or four SeqA foci. The results indicate that during rapid growth more than two replication forks are often co-localized.

\section{DISCUSSION}

\section{A method for direct detection of late-firing origins}

We report here a method for detecting the exact point of initiation of ChrII replication in $V$. cholerae. In principle 
(a)

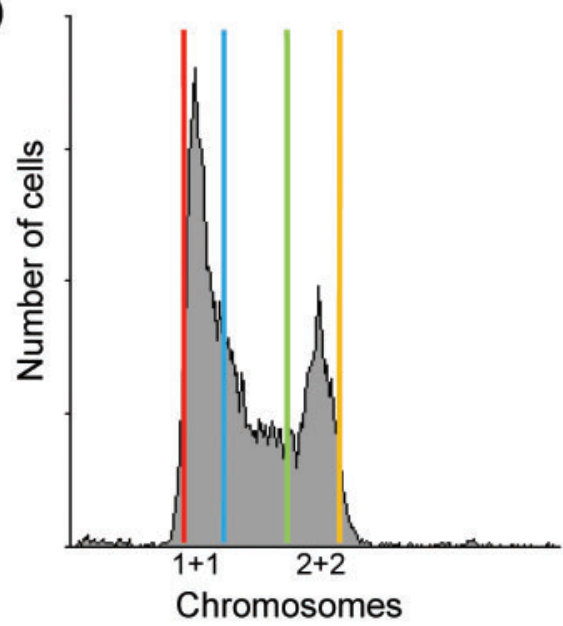

(b)
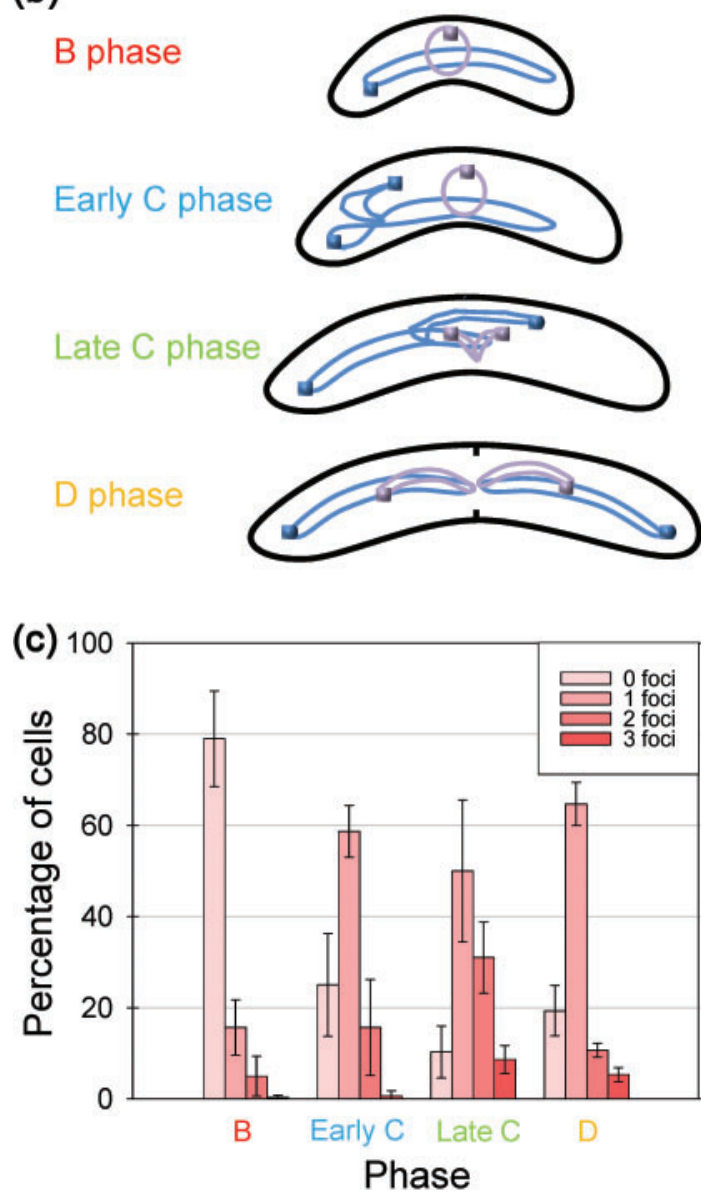

this method can be used for any organism, provided replication occurs in a regulated manner from specific origins. The method is based on the fact that in a theoretical DNA histogram, the number of cells with a given DNA content will drop to around half (from one channel to the next) when the number of replication forks (and the rate of DNA synthesis) is doubled. This means that the higher the total DNA synthesis rate, the fewer the
Fig. 6. Cell cycle distribution of SeqA foci in V. cholerae. (a) Cells grown in fructose medium were sorted from four narrow DNA intervals, as indicated by the four coloured lines on the DNA distribution. (b) Illustration of chromosome configurations in each sorted interval (Egan et al., 2005; Srivastava et al., 2006). In the B phase (red FACS interval), cells contain one Chrl (blue) and one Chrll (purple) but no replication forks. In early C (blue FACS interval), cells contain two Chrl replication forks, and in late $\mathrm{C}$ (green FACS interval), also two Chrll replication forks, i.e. four forks in total. In the D phase (yellow FACS interval), cells contain two of each chromosome and no forks. (c) Cells from these intervals were immunostained with anti-SeqA antibody and subjected to fluorescence microscopy, and the numbers of SeqA foci per cell were determined.

cells per channel. Likewise the number of cells per channel will increase when replication forks finish. Thus, the initiation and termination points can be read directly from the shape of the DNA histogram.

\section{Simultaneous replication of two copies of Chrll}

In rich media the duration of the ChrII phases $\left(\mathrm{C}_{\mathrm{II}}+\mathrm{D}_{\mathrm{II}}\right)$ was found to be longer than one generation (one doubling time). The initiation of ChrII replication then occurred in the 'mother' generation, at two origins. It has earlier been reported that only ChrI (and not ChrII) can replicate with overlapping cycles; this is based on a microscopy study yielding mainly one and two oriII foci (Srivastava \& Chattoraj, 2007). A reason for this apparent discrepancy could be that the numbers of origin foci were taken by the authors to be equivalent to numbers of origins. However, if $V$. cholerae origins stay co-localized for some time after initiation, as shown for origins in rapidly growing E. coli (Fossum et al., 2007), the number of origins will be underestimated by this approach. Three and four oriII foci have been observed in another similar microscopy study of LB-grown cells (Saint-Dic et al., 2008), supporting our result. Also, in E. coli, both separate and co-localized origins have been observed in the same cell (giving the unexpected number of three foci), depending on the growth conditions (Adachi et al., 2008; Fossum et al., 2007; Nielsen et al., 2007).

\section{The control of Chrll copy number may be coupled to $\mathrm{Chrl}$ replication}

Our results suggest that ChrII replicates at the end of the ChrI replication period at all four growth rates tested, but that inhibition of transcription and protein synthesis leads to equal numbers of ChrI and ChrII in all cells. For instance, cells grown in glucose/CAA medium end with two ChrI and two ChrII or four ChrI and four ChrII after treatment with rifampicin and cephalexin. Most cells in the exponentially growing culture contained four oriI and two oriII. The absence of a population of cells with four ChrI and two ChrII indicates that initiation of ChrII is 
regulated in such a way that one ChrII is initiated for each copy of ChrI. The same tendency is seen for LB-grown cultures, in which cells harbour four oriI and two oriII or eight oriI and four oriII. After treatment with rifampicin and cephalexin, a subpopulation ends up with $4+4$ chromosomes, while the rest seem to continue towards a higher DNA content. We suggest that initiation of ChrII replication is directly or indirectly coupled to initiation of ChrI, but then inhibited until most of ChrI is replicated. The mechanisms for this regulation remain to be investigated and may involve components that to date are unknown. However, such regulation could in principle be achieved with the already known initiator proteins of ChrI and ChrII, DnaA and RctB. These proteins seem to be switched on and off by opposite signals. Whereas the active form of DnaA is the ATP-bound form, the active RctB has ADP bound (Duigou et al., 2008). It is possible that a mechanism similar to the E. coli RIDA mechanism (Katayama et al., 2001) exists in V. cholerae and causes hydrolysis of active ATP-DnaA to inactive ADP-DnaA as soon as ChrI forks are under way, preventing further initiation of ChrI. If the launching of ChrI forks also causes a gradual hydrolysis of ATP-RctB to the active ADP form, the mechanism could explain how replication of the two chromosomes can be coordinated without initiating at the same time. Such a mechanism would also explain why matching numbers of the two chromosomes accumulate after rifampicin treatment. In the presence of rifampicin, protein synthesis will cease, and also the synthesis of RctB. However, since all necessary RctB would already be present (but inactive), initiation can occur when ChrI forks have replicated for long enough and enough RctB-ATP is hydrolysed.

Alternatively, it could be that ChrII initiation is regulated independently of ChrI, but governed by common regulatory restrictions. For instance, a prolonged sequestration of oriII might explain the delay in ChrII replication. For such a mechanism to function, oriII would have to be sequestered for an entire generation (and then released after exactly one generation). If oriI were also sequestered for exactly one generation, the release from these sequestration events would be staggered and generate the delay. Measurements of the amounts of hemimethylated origin DNA in exponentially growing cultures indicate that either 40 and $20 \%$ (Saint-Dic et al., 2008) or 10 and 50 $70 \%$ (Demarre \& Chattoraj, 2010) of oriI and oriII sequences, respectively, are hemimethylated. The measurements depend on which diagnostic GATC site is used in the measurement, and especially the latter result may support the idea that oriII initiation is prevented for an entire generation. It is, however, not clear how separate, staggered sequestration windows (or only the orill sequestration window) would operate in a precise fashion. The release from sequestration of the last GATC site in oriII (or at least the last site that prevents initiation) would in this case have to be quite precisely timed. Such a prolonged sequestration mechanism would also imply that during slow growth all
B-period cells would contain origins in sequestration. In the present experiments we found only a few B-period cells with SeqA foci. Thus, if oriII-SeqA structures are present during the B period, they are for some reason not detected by the immunofluorescence microscopy.

\section{Flexible co-localization of pairs of replication forks during slow growth}

Segregation of ChrI in $V$. cholerae is dependent on the ParAI and ParBI proteins, which act on a centromere-like site near oriI and pull the origin region of one of the replicated chromosomes from the old pole to the new pole (Fiebig et al., 2006; Fogel \& Waldor, 2005, 2006). The origin of ChrII is localized at the cell centre and is reported to move independently of ChrI to the quarter positions of the cell after replication (Fiebig et al., 2006; Fogel \& Waldor, 2005). Thus, the segregation of the two chromosomes seems to be by separate mechanisms.

For $V$. cholerae cells grown in glycerol medium $(\tau=$ $107 \mathrm{~min}$ ), our results indicate that pairs of replication forks co-localize. Since short cells in early C phase (with replication of ChrI alone) contain one SeqA focus, and longer cells in late $\mathrm{C}$ (with replication of both chromosomes) two foci, replication forks originating from the same origin are probably co-localized. The indication that the two ChrI forks are localized separately from the two ChrII forks supports the notion that the two chromosomes segregate by separate mechanisms. For cells grown in fructose medium ( $\tau=46 \mathrm{~min}$ ), we observed in addition a few cells with three foci, which may suggest that the co-localization is somewhat flexible. The sorting confirmed that the cells with three foci contained a DNA amount corresponding to late $\mathrm{C}$ phase, which supports the finding that replication of ChrII occurs during the latter part of C. Many cells sorted from late C contained only one SeqA focus. This may have been caused by co-localization of all of the replication forks. Due to biological variation some cells sorted from the late C-phase DNA interval may also actually be early C- or D-phase cells. Note that the resolution of the microscope allows a determination of co-localization within a distance of not less than $200 \mathrm{~nm}$. Thus, it is not clear whether the single focus represents one or several separate SeqA structures at this resolution.

\section{Further co-localization of replication forks during segregation of multi-fork chromosomes}

In E. coli it has been found that the SeqA protein may be involved in the organization of new DNA at the replication forks (Fossum et al., 2007; Hiraga et al., 1998; Molina \& Skarstad, 2004). The structures formed by SeqA are largely independent of the exact numbers of replication forks, and seem to be present in numbers roughly proportional to cell size (Morigen et al., 2009; Odsbu et al., 2009). In cells with multi-forked chromosomes, it has been suggested that new replication forks latch onto existing SeqA structures, and are 
thus confined to the correct cell half (Morigen et al., 2009). Our findings of limited numbers of SeqA foci during rapid growth may support the idea of both separate localization and segregation of the two $V$. cholerae chromosomes, and an extensive co-localization of the forks on the same multi-fork chromosome. The fact that we only found cells with $2+2$ or $4+4$ chromosomes after drug treatment may be a consequence of regulatory mechanisms that ensure that matching numbers of the two chromosomes are replicated. This result is compatible with separate mechanisms for segregation of ChrI and ChrII.

In E. coli, deletion of the seqA gene leads to reinitiation at already initiated origins, changes in the superhelicity and organization of the chromosome, and a reduced growth rate in rich medium ( $\mathrm{Lu}$ et al., 1994; Waldminghaus \& Skarstad, 2009; Weitao et al., 2000). In V. cholerae, it has been reported that a seqA null mutant cannot be constructed, indicating that the SeqA protein is essential and thus more important for this organism than it is for $E$. coli (Egan \& Waldor, 2003; Saint-Dic et al., 2008). Even though a seqA null mutant has since been studied, showing that under certain conditions loss of SeqA can be tolerated (Demarre \& Chattoraj, 2010), the SeqA protein may still be more important in $V$. cholerae than in E. coli. It is possible that because of the two-chromosome organization of the $V$. cholerae genome, this organism has a requirement for a more extensive origin sequestration or a more advanced degree of fork organization.

\section{ACKNOWLEDGEMENTS}

We are grateful to Ole Skovgaard for providing strain 2740-80 and the Excel simulation program from which we derived the program used in Supplementary Fig. S1(a, b), and to Kirsti Solberg Landsverk and Idun Dale Rein for assistance with cell sorting at the Flow Cytometry Core Facility. We thank Anne Wahl and Ingvild Odsbu for assistance with molecular biology protocols. We also wish to thank Erik Boye and Trond Stokke for critical reading of the manuscript.

\section{REFERENCES}

Adachi, S., Fukushima, T. \& Hiraga, S. (2008). Dynamic events of sister chromosomes in the cell cycle of Escherichia coli. Genes Cells 13, 181-197, doi:10.1111/j.1365-2443.2007.01157.x.

Allardet-Servent, A., Michaux-Charachon, S., Jumas-Bilak, E., Karayan, L. \& Ramuz, M. (1993). Presence of one linear and one circular chromosome in the Agrobacterium tumefaciens C58 genome. $J$ Bacteriol 175, 7869-7874.

Boye, E. \& Løbner-Olesen, A. (1991). Bacterial growth control studied by flow cytometry. Res Microbiol 142, 131-135, doi:10.1016/ 0923-2508(91)90020-B.

Bremer, H. \& Churchward, G. (1977). An examination of the Cooper-Helmstetter theory of DNA replication in bacteria and its underlying assumptions. J Theor Biol 69, 645-654, doi:10.1016/00225193(77)90373-3.

Brendler, T., Abeles, A. \& Austin, S. (1995). A protein that binds to the $\mathrm{P} 1$ origin core and the oriC 13 mer region in a methylation-specific fashion is the product of the host seqA gene. EMBO J 14, 4083-4089.
Brendler, T., Sawitzke, J., Sergueev, K. \& Austin, S. (2000). A case for sliding SeqA tracts at anchored replication forks during Escherichia coli chromosome replication and segregation. EMBO J 19, 6249-6258, doi:10.1093/emboj/19.22.6249.

Campbell, J. L. \& Kleckner, N. (1990). E. coli oriC and the dnaA gene promoter are sequestered from dam methyltransferase following the passage of the chromosomal replication fork. Cell 62, 967-979, doi:10.1016/0092-8674(90)90271-F.

Clark, D. J. \& Maaloe, O. (1967). DNA replication and division cycle in Escherichia coli. J Mol Biol 23, 99-112, doi:10.1016/S00222836(67)80070-6.

Cooper, S. \& Helmstetter, C. E. (1968). Chromosome replication and the division cycle of Escherichia coli B/r. J Mol Biol 31, 519-540, doi:10.1016/0022-2836(68)90425-7.

Demarre, G. \& Chattoraj, D. K. (2010). DNA adenine methylation is required to replicate both Vibrio cholerae chromosomes once per cell cycle. PLoS Genet 6, e1000939, doi:10.1371/journal.pgen.1000939.

Dryselius, R., Izutsu, K., Honda, T. \& lida, T. (2008). Differential replication dynamics for large and small Vibrio chromosomes affect gene dosage, expression and location. BMC Genomics 9, 559, doi:10.1186/1471-2164-9-559.

Duigou, S., Knudsen, K. G., Skovgaard, O., Egan, E. S., Løbner-Olesen, A. \& Waldor, M. K. (2006). Independent control of replication initiation of the two Vibrio cholerae chromosomes by DnaA and RctB. J Bacteriol 188, 6419-6424, doi:10.1128/JB.00565-06.

Duigou, S., Yamaichi, Y. \& Waldor, M. K. (2008). ATP negatively regulates the initiator protein of Vibrio cholerae chromosome II replication. Proc Natl Acad Sci U S A 105, 10577-10582, doi:10.1073/ pnas.0803904105.

Egan, E. S. \& Waldor, M. K. (2003). Distinct replication requirements for the two Vibrio cholerae chromosomes. Cell 114, 521-530, doi:10.1016/S0092-8674(03)00611-1.

Egan, E. S., Løbner-Olesen, A. \& Waldor, M. K. (2004). Synchronous replication initiation of the two Vibrio cholerae chromosomes. Curr Biol 14, R501-R502, doi:10.1016/j.cub.2004.06.036.

Egan, E. S., Fogel, M. A. \& Waldor, M. K. (2005). Divided genomes: negotiating the cell cycle in prokaryotes with multiple chromosomes. Mol Microbiol 56, 1129-1138, doi:10.1111/j.1365-2958.2005. 04622.x.

Fiebig, A., Keren, K. \& Theriot, J. A. (2006). Fine-scale time-lapse analysis of the biphasic, dynamic behaviour of the two Vibrio cholerae chromosomes. Mol Microbiol 60, 1164-1178, doi:10.1111/j.13652958.2006.05175.x.

Fogel, M. A. \& Waldor, M. K. (2005). Distinct segregation dynamics of the two Vibrio cholerae chromosomes. Mol Microbiol 55, 125-136, doi:10.1111/j.1365-2958.2004.04379.x.

Fogel, M. A. \& Waldor, M. K. (2006). A dynamic, mitotic-like mechanism for bacterial chromosome segregation. Genes Dev 20, 3269-3282, doi:10.1101/gad.1496506.

Fossum, S., Crooke, E. \& Skarstad, K. (2007). Organization of sister origins and replisomes during multifork DNA replication in Escherichia coli. EMBO J 26, 4514-4522, doi:10.1038/sj.emboj.7601871.

Gilbert, D. M. (2001). Making sense of eukaryotic DNA replication origins. Science 294, 96-100, doi:10.1126/science.1061724.

Heidelberg, J. F., Eisen, J. A., Nelson, W. C., Clayton, R. A., Gwinn, M. L., Dodson, R. J., Haft, D. H., Hickey, E. K., Peterson, J. D. \& other authors (2000). DNA sequence of both chromosomes of the cholera pathogen Vibrio cholerae. Nature 406, 477-483, doi:10.1038/ 35020000 .

Hiraga, S., Ichinose, C., Niki, H. \& Yamazoe, M. (1998). Cell cycledependent duplication and bidirectional migration of SeqA-asso- 
ciated DNA--protein complexes in E. coli. Mol Cell 1, 381-387, doi:10.1016/S1097-2765(00)80038-6.

Hiraga, S., Ichinose, C., Onogi, T., Niki, H. \& Yamazoe, M. (2000). Bidirectional migration of SeqA-bound hemimethylated DNA clusters and pairing of oriC copies in Escherichia coli. Genes Cells 5, 327-341, doi:10.1046/j.1365-2443.2000.00334.x.

Katayama, T., Fujimitsu, K. \& Ogawa, T. (2001). Multiple pathways regulating DnaA function in Escherichia coli: distinct roles for DnaA titration by the datA locus and the regulatory inactivation of DnaA. Biochimie 83, 13-17, doi:10.1016/S0300-9084(00)01206-2.

Koch, B., Ma, X. F. \& Løbner-Olesen, A. (2010). Replication of Vibrio cholerae chromosome I in Escherichia coli: dependence on Dam methylation. J Bacteriol 192, 3903-3914, doi:10.1128/JB.00311-10.

Løbner-Olesen, A., Skovgaard, O. \& Marinus, M. G. (2005). Dam methylation: coordinating cellular processes. Curr Opin Microbiol 8, 154-160, doi:10.1016/j.mib.2005.02.009.

Lu, M., Campbell, J. L., Boye, E. \& Kleckner, N. (1994). SeqA: a negative modulator of replication initiation in E. coli. Cell 77, 413426, doi:10.1016/0092-8674(94)90156-2.

Molina, F. \& Skarstad, K. (2004). Replication fork and SeqA focus distributions in Escherichia coli suggest a replication hyperstructure dependent on nucleotide metabolism. Mol Microbiol 52, 1597-1612, doi:10.1111/j.1365-2958.2004.04097.x.

Morigen, Odsbu, I. \& Skarstad, K. (2009). Growth rate dependent numbers of SeqA structures organize the multiple replication forks in rapidly growing Escherichia coli. Genes Cells 14, 643-657, doi:10.1111/ j.1365-2443.2009.01298.x.

Nielsen, H. J., Youngren, B., Hansen, F. G. \& Austin, S. (2007). Dynamics of Escherichia coli chromosome segregation during multifork replication. J Bacteriol 189, 8660-8666, doi:10.1128/JB.01212-07.

Odsbu, I., Morigen \& Skarstad, K. (2009). A reduction in ribonucleotide reductase activity slows down the chromosome replication fork but does not change its localization. PLoS ONE 4, e7617, doi:10.1371/journal.pone.0007617.

Okada, K., lida, T., Kita-Tsukamoto, K. \& Honda, T. (2005). Vibrios commonly possess two chromosomes. J Bacteriol 187, 752-757, doi:10.1128/JB.187.2.752-757.2005.

Onogi, T., Niki, H., Yamazoe, M. \& Hiraga, S. (1999). The assembly and migration of SeqA-Gfp fusion in living cells of Escherichia coli. Mol Microbiol 31, 1775-1782, doi:10.1046/j.1365-2958.1999.01313.x.

Pearson, G. D. N., Woods, A., Chiang, S. L. \& Mekalanos, J. J. (1993). CTX genetic element encodes a site-specific recombination system and an intestinal colonization factor. Proc Natl Acad Sci U S A 90, 3750-3754, doi:10.1073/pnas.90.8.3750.

Rasmussen, T., Jensen, R. B. \& Skovgaard, O. (2007). The two chromosomes of Vibrio cholerae are initiated at different time points in the cell cycle. EMBO J 26, 3124-3131, doi:10.1038/sj.emboj. 7601747.

Saint-Dic, D., Kehrl, J., Frushour, B. \& Kahng, L. S. (2008). Excess SeqA leads to replication arrest and a cell division defect in Vibrio cholerae. J Bacteriol 190, 5870-5878, doi:10.1128/JB.00479-08.
Skarstad, K., Steen, H. B. \& Boye, E. (1985). Escherichia coli DNA distributions measured by flow cytometry and compared with theoretical computer simulations. J Bacteriol 163, 661-668.

Skarstad, K., Boye, E. \& Steen, H. B. (1986). Timing of initiation of chromosome replication in individual Escherichia coli cells. EMBO J 5, 1711-1717.

Slater, S., Wold, S., Lu, M., Boye, E., Skarstad, K. \& Kleckner, N. (1995). E. coli SeqA protein binds oriC in two different methylmodulated reactions appropriate to its roles in DNA replication initiation and origin sequestration. Cell 82, 927-936, doi:10.1016/ 0092-8674(95)90272-4.

Srivastava, P. \& Chattoraj, D. K. (2007). Selective chromosome amplification in Vibrio cholerae. Mol Microbiol 66, 1016-1028, doi:10.1111/j.1365-2958.2007.05973.x.

Srivastava, P., Fekete, R. A. \& Chattoraj, D. K. (2006). Segregation of the replication terminus of the two Vibrio cholerae chromosomes. J Bacteriol 188, 1060-1070, doi:10.1128/JB.188.3.1060-1070.2006.

Suwanto, A. \& Kaplan, S. (1989). Physical and genetic mapping of the Rhodobacter sphaeroides 2.4.1 genome: presence of two unique circular chromosomes. J Bacteriol 171, 5850-5859.

Torheim, N. K., Boye, E., Løbner-Olesen, A., Stokke, T. \& Skarstad, K. (2000). The Escherichia coli SeqA protein destabilizes mutant DnaA204 protein. Mol Microbiol 37, 629-638, doi:10.1046/j.13652958.2000.02031.x.

Trucksis, M., Michalski, J., Deng, Y. K. \& Kaper, J. B. (1998). The Vibrio cholerae genome contains two unique circular chromosomes. Proc Natl Acad Sci U S A 95, 14464-14469, doi:10.1073/pnas.95.24.14464.

Vesth, T., Wassenaar, T. M., Hallin, P. F., Snipen, L., Lagesen, K. \& Ussery, D. W. (2010). On the origins of a Vibrio species. Microb Ecol 59, 1-13, doi:10.1007/s00248-009-9596-7.

von Freiesleben, U., Rasmussen, K. V. \& Schaechter, M. (1994). SeqA limits DnaA activity in replication from oriC in Escherichia coli. Mol Microbiol 14, 763-772, doi:10.1111/j.1365-2958.1994.tb01313.x.

Waldminghaus, T. \& Skarstad, K. (2009). The Escherichia coli SeqA protein. Plasmid 61, 141-150, doi:10.1016/j.plasmid.2009.02.004.

Waldminghaus, T. \& Skarstad, K. (2010). ChIP on Chip: suprising results are ofen artifacts. BMC Genomics 11, 414.

Weitao, T., Nordström, K. \& Dasgupta, S. (2000). Escherichia coli cell cycle control genes affect chromosome superhelicity. EMBO Rep 1, 494-499.

Wigley, P. \& Burton, N. F. (2000). Multiple chromosomes in Burkholderia cepacia and B. gladioli and their distribution in clinical and environmental strains of B. cepacia. J Appl Microbiol 88, 914-918, doi:10.1046/j.1365-2672.2000.01033.x.

Woodfine, K., Fiegler, H., Beare, D. M., Collins, J. E., McCann, O. T., Young, B. D., Debernardi, S., Mott, R., Dunham, I. \& Carter, N. P. (2004). Replication timing of the human genome. Hum Mol Genet 13, 191-202, doi:10.1093/hmg/ddh016.

Edited by: T. den Blaauwen 